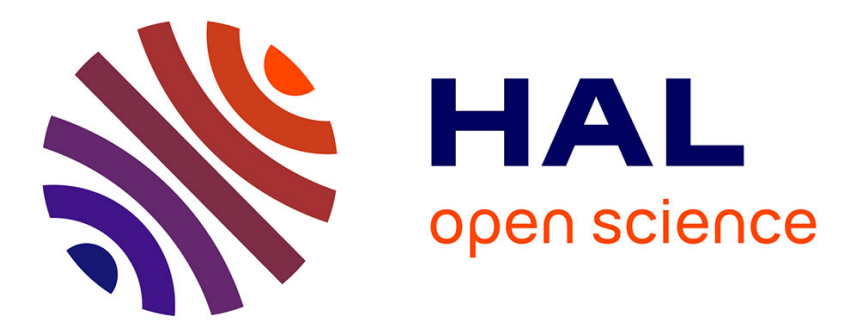

\title{
Monetary income, public funds, and subsistence consumption: the three components of the food supply in French Polynesia - a comparative study of Tahiti and Rapa Iti islands
}

Christophe Serra-Mallol

\section{To cite this version:}

Christophe Serra-Mallol. Monetary income, public funds, and subsistence consumption: the three components of the food supply in French Polynesia - a comparative study of Tahiti and Rapa Iti islands. Review of Agricultural, Food and Environmental Studies, 2018, 99 (1), pp.37-55. 10.1007/s41130017-0057-2 . hal-02963400

\author{
HAL Id: hal-02963400 \\ https://hal.science/hal-02963400
}

Submitted on 16 Oct 2020

HAL is a multi-disciplinary open access archive for the deposit and dissemination of scientific research documents, whether they are published or not. The documents may come from teaching and research institutions in France or abroad, or from public or private research centers.
L'archive ouverte pluridisciplinaire HAL, est destinée au dépôt et à la diffusion de documents scientifiques de niveau recherche, publiés ou non, émanant des établissements d'enseignement et de recherche français ou étrangers, des laboratoires publics ou privés. 
Pré-print of Serra-Mallol Christophe, 2018. "Monetary income, public funds, subsistence consumption: the three components of the food supply in French Polynesia. A comparative study of Tahiti and Rapa iti islands". Review of Agricultural, Food and Environmental Studies, 99-1, p. 37-55.

DOI : 10.1007/s41130-017-0057-2

The final publication is available at link.springer.com

\section{Monetary income, public funds, subsistence consumption: the three components of the food supply in French Polynesia. A comparative study of Tahiti and Rapa iti islands.}

\section{Introduction}

Ancient Polynesian society was studied by the first anthropologists, and research in this field has followed the discipline's development since then. For Marcel Mauss this is the model of a society governed by a system of reciprocal giving, a "system of total services" système de prestations totales (1950), the institutionalised flow of food exchanges, both voluntary and obligatory, connecting humans to each other and to the gods. Economic commercialisation does not preclude the persistence of those relationships, which maintain a network of exchanges outside the monetary economy, and so European colonisation and then the recent trend of globalisation have been accompanied by a counter-trend of localisation which asserts a strong sense of identity, especially in relation to food. How have historical and political factors, with their consequences in terms of choice and availability of foodstuffs, influenced contemporary Polynesian food provision practices?

This chapter presents a comparative and diachronic analysis of food provision and consumption patterns in French Polynesia, and of the social factors and dynamics driving these patterns. Two island territories, the island of Tahiti, ${ }^{1}$ the location of the capital city and the most urbanised island in the French overseas territorial unit, and the island of Rapa, ${ }^{2}$ the most isolated of these islands, located $1,250 \mathrm{~km}$ from the former, constitute the comparative research areas used to illustrate the arguments presented here. An outline of how Polynesians' methods of food provision and consumption have evolved is followed by an analysis of the

\footnotetext{
${ }^{1}$ Field research on food practices and representations undertaken between 2002 and 2006, based on contextualised observations of around 40 households in two neighbourhoods in Tahiti and Moorea, qualitative individual and group interviews in the Society Islands archipelago, and a quantitative survey of a sample of more than 500 households in Tahiti.

${ }^{2}$ Field research on food practices and representations undertaken on the island of Rapa over a cumulative period of seven months in 2009-2011, based on contextualised observations, qualitative interviews and personal narratives, a quantitative survey of more than $70 \%$ of the adult population, supplemented by a study of non-resident Rapans in Tahiti. The Qualirapa project was supported by the French Agence Nationale de la Recherche (National Research Agency).
} 
three component elements of Polynesian food resources: monetary resources, public finance, and subsistence consumption (comprising subsistence production plus gifts and exchanges), all of which still operate in varying degrees depending on the location. Lastly, this chapter shows how the negative impacts of the current mode of food production and consumption favour the emergence of a determination to regain control of these resources, through the example of Rapa where food and food practices have been given renewed meaning by reembedding the economic within its social and cultural substrate (Polanyi, 1957).

\section{1- How Polynesian foodways have evolved}

The key phases in the evolution of the food system in French Polynesia are Christianisation and monetisation, followed by colonisation in the 19th century, and then by massive financial inflows during the French nuclear era from the 1960s onward. These phases are characterised by the imposition of external values and by the interpretation of a formal, European framework via local categories (Serra-Mallol, 2013).

\section{1- The pre-European food system}

\subsection{1- A subsistence economy}

The socio-economic practices of the ancient Polynesians are well known to us, especially those of the Tahitians (Oliver, 1974; Robineau, 1985; Baré, 1987), as are the food distribution and supply patterns of the pre-European era (Pollock, 1992; Serra-Mallol, 2010). The ancient Polynesians derived their food supply from the exploitation of introduced local land-based resources and marine resources. Their knowledge of these various resources was highly sophisticated, encompassing multiple varieties of a relatively limited number of plant and marine species and the use of specially adapted fishing, agricultural and horticultural techniques appropriate to a humid tropical climate, plus hunting, gathering and semi-domestic livestock rearing.

In ancient Polynesian society, the extended family home was the basic unit where daily food production was organised and the focal point around which was structured a network of exchanges with other households and the rest of the community. This cooperative group, called 'opu or 'ati (Robineau, 1985) comprised successive generations of a common lineage living in a single household, organised around a common ancestor and a shared plot of land, the fenua, a key component of Polynesian identity (Baré, 1987). This group was responsible for the day-to-day management of the land and of marine resources, owning most of the tools of collective production (large fishing nets, canoes, etc.). These family groups were connected at a higher level by an integrated community-based system for managing land and sea, the 
mata'eina'a: a community led by an ari'i (or ariki in Rapa) - the hereditary chief (following the rule of primogeniture) and custodian of the land. Polynesian societies, then, were highly structured and hierarchical, organised around the concept of mana, their dominant values being the prestige and honour of the chief and his community, and reciprocity.

An individual's status, gender and age were the criteria used to differentiate and categorise, determining which foods they were permitted to eat and the way these foods were produced and consumed. Status was determined by genealogical proximity to the relevant deified ancestor, the quality of mana being to some extent its symbolic expression, inherited in greater amounts by those closest to the rank of chief: the most prestigious foods (red-meat animals, pelagic fish, the most highly prized plant foods), and their production and preparation, were ritually dedicated to the most sacred, $r a^{\prime} a$, individuals. Conversely, the range of foodstuffs became more limited in quantity and quality as the degree of genealogical separation increased: the least sacred families and individuals were subjected to the largest number of segregations and prohibitions.

Across Polynesia we see clear gender-based segregation, extending from the selection of permitted foods through to their modes of production and storage, distribution and consumption (Serra-Mallol, 2010). Yet this criterion was secondary to leader status, in the Society Islands at least, while status and gender were more strongly linked in Rapa, to the benefit of the male sex (Moerenhout, 1959). At all levels food itself was regarded as tapu, sacred, and therefore a source of distinction and segregation.

Ancient Polynesians' daily diet was therefore located within a prescribed order, defined in terms of the basic foodstuffs, in which every individual, according to his or her status, could access specified food resources at a given place and time: certain varieties of breadfruit, 'uru, and taro in Tahiti (the peninsula), taro in Rapa, other plant foods (yam, sweet potato, ancient cassava, etc.), coconut milk as a distinctive feature of the Tahitian diet (coconut, banana, plantain and breadfruit do not grow in Rapa), accompanied by fish and a sea water sauce. A rahui, a periodic prohibition or restriction decreed by the chief for one or more primary foodstuffs or for a given maritime area, and covering production, trading and consumption, could be issued at any time. Eaters were clearly segregated - physically as well as by permitted foods - and the most highly valued foodstuffs were reserved for gifts to chiefs and the gods, and for the many festive and ritual occasions that structured daily life, bringing family leaders together. The redistribution specific to the role of chief - in the form of regular gigantic feasts, lasting several days - represented a form of reciprocity between the chief and his community, which regularly paid him tributes, mainly of food. The prestige of the 
abundance on offer at these occasions reflected on the whole community; leftovers were distributed equitably among all the guests to be taken home afterwards.

\subsection{2- An economy of gifts and exchanges}

In Polynesia, in the absence of money and of markets as physical trading places, four forms of food provision could co-exist (Oliver, 1974): the pooling of resources and of production and storage capacities for mutual assistance (tauturu); regular exchanges between households (tarahu and ho'o) and other spatial and temporal forms of sharing; individual hospitality (aro'a) or collective hospitality ('utu) in the form of offering one's own resources for a visit by an honoured guest or a community event; and providing accommodation for a relative ( $\left.f a^{\prime} a^{\prime} a m u ' a\right)$ in the home - in addition to the tributes, including food tributes, paid periodically to chiefs. All these types of distribution - except the last one - are still found in the same forms today (Serra-Mallol, 2010).

According to the generally accepted principle of reciprocity, the food used for gifts, exchanger, or barter for a specialist service, had a value beyond the mere use or exchange values: a bonding value (Godbout, 1992). These phenomena of gifts, exchange, and sharing therefore provide a base reference point for understanding the society as a whole: "the entire ma'ohi social world can be seen as expressing itself via food practices and food production" (Baré, 1987). Polynesian societies were based on the economic driving force of gifts and exchanges, reciprocity and redistribution, via social relationships that bound individuals closely to one another and to their community, and the economic dimension was embedded in social and cultural relationships - these being crystallised, in one particular form, in their food practices. These societies were highly integrative, defining precise status classifications for individuals and situations, as evidenced by the number and degree of food prohibitions and restrictions. But they were also highly segregated and hierarchical in the differentiated access to food they offered to their members.

\section{2- $\quad$ First contacts with the monetary economy}

\subsection{1- The spread of Christian and Western values}

There is little evidence of foreign foods being successfully introduced - and accepted by Polynesians - during the first years after contact was made with Europeans in the last quarter of the 18th century for Tahiti and the first quarter of the following century for Rapa. Initially European foods were reputed to be bad or ineffective and their distribution was limited confined for an initial period to the exchange networks between chiefs and their allies. Then 
contacts increased with ships trading in whale oil and tropical hardwoods, and with trading vessels that were passing through, and the chiefs became incorporated in these transoceanic trade networks, diverting a portion of the traditional flows of gift and exchange accordingly, which effectively withdrew them from the traditional redistribution cycle.

During the 19th century, Christianity became the dominant religion in a number of Polynesian socio-political groupings - including the Society Islands and Rapa (in the Austral Islands) from the 1820s-30s onwards. It is only at this point that we see the Society Islands and Rapa join the market economy, mainly through the trade in salt pork and coconut oil established by chiefs and missionaries in Tahiti, and the trade in pearls and mother-of-pearl in Rapa (Caillot, 1932). The transition from a gift and exchange economy to a monetary economy occurred as a result of the voluntaristic action of missionaries, who needed to participate in existing trade networks in order to procure consumer goods for their own use (flour, salt beef, cloth, etc.) from the European mainland, and sought to involve their new converts in these networks, too. The challenge was to "increase their wants, or to make some of the comforts and decencies of society as desirable as the bare necessities of life" as Ellis (1829) wrote.

Despite the introduction of bread and wine by the Christian missionaries, and of a few other new foodstuffs (mainly pulses), in both Tahiti and Rapa from the 1830s onward, the everyday diet of Polynesian families remained very largely unchanged, exclusively self-sufficient and based on traditional resources. Yet the symbolic and temporal aspect of the new, normative Christian order disrupted the structure and meaning of their day-to-day arrangements, and even the status of the eater (Serra-Mallol, 2010). The ancient practices of food segregation gave way to a syncretic Christian model which became the new "food tradition". Religion also wielded its influence through domestic education lessons in housekeeping and food responsibilities - including new methods for preparing and presenting the recently introduced foods (cooking by boiling in a recipient, use of cutlery, setting a table, etc.) - provided for native girls by pastors' wives and Catholic nuns across the Pacific islands (Pollock, 1992).

Tahitian society was structured around the basic unit of the family, the household, which gave missionaries the illusion of recreating a perfectly Christian world - an endeavour simultaneously replicated by British ministers in Rapa. The internalisation of these new behaviour norms initially distanced the practices of the group of chiefs from the rest of the population, with the utensils accompanying these norms (cutlery, plates, glasses - but also tables and table etiquette) subsequently becoming widespread among the population as a whole via gifts and exchanges following the constellations of family alliances. The first radical change to the Polynesian food model therefore occurred with its progressive 
conversion to the European and Christian model, locating it within a more open understanding of the world of food and desacralising ancient prohibitions, in a mercantile context.

\subsection{2- A colonial trading-post economy}

The arrival of the French, ${ }^{3}$ combined with a voluntaristic agricultural policy from the second half of the 19th century onwards, led to the introduction of speculative agriculture driven by global prices for tropical products: coconut oil (from the copra or kernel), cotton and vanilla in Tahiti, sugar cane and oranges in Tahiti and Rapa, and coffee in Rapa - which became the leading Polynesian coffee producer. The production of these export commodities required a substantial and cheap labour force made up of local people, who worked as and when they needed money, but also including islanders from elsewhere in the Pacific and, from 1865 onwards, Chinese workers some of whom decided to remain. The growing population from the French mainland required dedicated provisioning with European-style foods, hence the creation of Papeete's communal market in 1850, supplied on a daily basis by Chinese market gardeners and by native farmers and fishers. As Chinese migrants were not permitted to acquire land or work in the civil service, from 1900 onwards they gradually took control of most of the retail sector and a large portion of the wholesale sector, supplying Papeete with fresh produce via intensive market-gardening operations on tenanted land. They became Tahitians' intermediaries with the monetary economy, mainly via the provision of credit facilities. At this point there were two economies operating simultaneously: a monetary economy in Tahiti and the nearby settlements where the Europeans lived, the new centre of the French Establishments in Oceania, and a subsistence economy in rural Polynesia - the districts and islands distant from Tahiti - with the Chinese trading community providing an economic point of contact between the two.

Except in Papeete, the centre of the colonial trading-post economy, Polynesians still lived in village communities made up of extended families deriving their food resources primarily from subsistence consumption. Under the leadership of their traditional chiefs - some of whom were now district chiefs, while others had become pastors (or priests) - they continued the tradition of great reciprocal festivities, which had a triple significance: expressing cooperation within the community, competition between communities, and redistribution between chiefs and the people (Robineau, 1985). Their surplus production was either bartered

\footnotetext{
${ }^{3}$ In Tahiti, France declared a Protectorate over the local royal government in 1842 and imposed direct administration after annexation in 1880 . This process had an extra component in Rapa, which became a Tahitian Protectorate in 1867, then a French Protectorate in 1881 before annexation in 1887.
} 
within the wider network of family relationships connecting the households or sold at Papeete market.

From 1902 onwards, Rapa was in regular communication with Tahiti - a dozen times a year and between 1903 and 1914 there was some discussion, during construction of the Panama Canal, of making Rapa the major French port in the Pacific. This project was abandoned, however. The port and naval base were finally built in Tahiti, and Rapa fell back into neglect: from the 1930s to the 1950s the island was visited by just one ship per year, a trading schooner sent from Tahiti to exchange merchandise for coffee. In the 1960s, food production and preparation activities still represented a major component of daily life for Rapa's inhabitants, retaining a strong symbolic significance (Hanson, 1970).

In the 20th century, the changes introduced by the first Europeans and missionaries could be seen in the new basic foodstuffs - flour, sugar, dried vegetables, rice, tinned foods, etc. available in neighbourhood stores in Tahiti, and in the orange and coffee now produced in Rapa alongside local foods. Food-crop production supported virtually the whole population up until 1940, except in Papeete and the surrounding conurbation - a situation that even continued through to the 1970s in Rapa where fish and taro remained the main subsistence foods.

The monetisation of trade accelerated when jobs were created by the phosphate mine in Makatea - jobs which gradually brought basic household goods into all Polynesian homes between its establishment in 1911 and the exhaustion of its deposits in the 1950s. By this time the Polynesian food model had practically disappeared in Papeete and the monetary component of the food system was expanding even in the remote islands.

\section{3- The monetisation of Polynesian society}

\subsubsection{An economy of public fund transfers and hyperconsumption}

Polynesian society became more widely integrated within the monetary economy with the creation of infrastructures for French nuclear tests between 1966 and 1996. This brought a move from a combined economy - subsistence production on the islands, export and monetary economy in Tahiti - to an economy based on massive transfers of public funds and import-dependent over-consumption: since the 1960s, state funding has accounted for more than a quarter of Polynesian gross domestic product (Délégation aux Etats Généraux, 2009). The Papeete conurbation grew substantially, its population more or less doubling between 1962 and 1971, mainly driven by inter-island migration. 
Total expenditure by the French army grew from 5\% of French Polynesia's gross domestic product in 1962 to a high point of $76 \%$ in 1966, the year of the first nuclear test, steadily decreasing in subsequent years and stabilising at around $20 \%$ in the $1980 \mathrm{~s}$. At the same time, payment of civil servant salaries increased the influx of cash: the public sector's share of the working population increased from $9 \%$ in 1956 to $35 \%$ in the 1980 s. Since then, the burden of the territory's civil service in its budget partly explains the high level of taxation, collected by its political institutions via a fiscal regime based on high indirect taxes (customs duties, VAT, etc.) levied on imported consumer goods. The massive increase of the public sector, pay hikes for national civil servants in the early 1960 s ( $+84 \%$ to $108 \%$, excluding allowances) and corresponding increases for local civil servants drove rapid growth in consumption and imports while traditional exports (copra, mother-of-pearl, vanilla, coffee) collapsed. The export/import coverage ratio decreased from $80 \%$ in the early 1960 s to around $25 \%$ in the 1980 , stagnating at around $10 \%$ in the 2000s-2010s. Since the early 1990 s, on average more than $80 \%$ of food products consumed in French Polynesia have been imported.

In the 1980s, per capita wealth became the highest of all the French overseas territories, comparable then to that of New Zealand. Yet the "rentier economy" owing to the nuclear programme caused wage inflation and high prices, exacerbating economic inequalities, while inflated growth in the tertiary sector was accompanied by a collapsing primary sector decreasing in the official statistics from $40 \%$ of the labour force in the early 1960s to $4 \%$ from the 1980s onward. Tahiti's growing urbanisation and the rapid monetisation of Tahitian society radically altered local food habits: Tahitians turned to imported food products, which increasingly supplanted local products. Less expensive to buy than local products due to being mass-produced, their constant availability in supermarkets and hypermarkets from the 1980s onwards ensured an abundant food supply - but one that had knock-on impacts in terms of Tahitians' economic dependency on the outside world (which steadily increased as the money economy grew), and food practices whose connections with health problems (obesity, diabetes, cardiovascular disease) are well documented.

This process was much slower in Rapa: after the establishment of the first school and the weather station in the 1950s, the presence of army-related personnel lasted only from 1964 to 1972, although it did comprise up to a quarter of the island's total population in this period. Regular contacts with the outside world brought supplies - leading to the dissemination of external goods and significant monetary circulation. The island created new infrastructures (construction of a whaling jetty in 1965, and a large ship wharf in 1970, which was enlarged in 2006); a shop opened to meet the needs of military personnel, supplied via maritime 
contacts with Tahiti; and a twice-yearly sea link was established to transport secondary school students. Yet even today the majority of the local population still lives from subsistence production based on taro cultivation and fishing.

\subsubsection{Subsistence consumption - a residual element of food provisioning?}

In Tahiti, with the commercialisation of the economy, the use of subsistence production is a less common phenomenon today among the households surveyed, despite the presence of fruit trees and vegetable patches in the gardens of people's homes, and proximity to the sea in all locations. The food of the past is perceived as having been freely available, but this way of providing for one's needs ('ohipa fa'apu ) is generally devalued in comparison to waged work ('ohipa moni).

For many Polynesian men, subsistence production signified their ability to feed their family properly and offer gifts beyond the immediate household. It was the pillar of a self-esteem that no longer exists in the same form today. In consequence, a head of household lacking permanent employment and no longer having access to this kind of food supply - due to a lack of land or loss of interest - can feel redundant, purposeless and confronted with a feeling of social shame, ha'a'ama, that plays an especially significant role in the Tahitian value system (Lévy, 1973). And the men view the growing of foods regarded as European (green beans, aubergines, tomatoes, etc.) in a different light to the cultivation of local "traditional" products: in general it is the women who handle this kind of local, utilitarian production. The monetisation of Tahiti's economy also led to a loosening of family ties, giving greater autonomy to the nuclear family unit (parents + children). Relations between descendants of the same parents are sometimes minimal in some families, either for personal reasons (wanting to spend time with the children in the evenings and at weekends) or due to the geographic distance between related households. The individualism of the urban consumer is increasingly replacing the multiple relationships of an eater embedded in wider family circles, and the sharing of resources is limited to exchanging prepared dishes and storing foods collectively in a community freezer.

Official statistics for Tahiti from the 1980s onwards show a growing proportion of food purchases being made in supermarkets and independent neighbourhood stores. The levels vary in accordance with the distance from Papeete: subsistence consumption becomes more important further from the capital city. Monetary income level is another key variable here: low-income households within the urban conurbation and in semi-rural areas operate in multiple areas simultaneously (farming/fishing/craft production) and consume part of their 
production, while households without work, or with precarious work or a basic pension, often people originally from the remote islands, supplement gifts they receive, or their ownership of a garden and a few animals, with state aid and a basic provisioning of subsidised essentials: sugar and coffee, oil and flour, rice, corned beef and cans of processed meat, fish, etc.

Rapa, meanwhile, has four foodstores, each with a sales area of less than $50 \mathrm{~m} 2$, one of them a plywood kiosk. Only a very small number of people - all of them civil servants - have personal accounts here and pay at the end of the month; other purchasers pay cash, never for sums in excess of around $€ 15$. These shops exclusively stock the few products from outside the island that arrive on a combined passenger-cargo ship every two to three months. The only fresh produce on offer during the author's stay was potatoes, carrots and onions, plus a few oranges and apples; the stores ran out of carrots after a fortnight, the onions and potatoes sold out after three weeks, and the sugar after a month, while the small amount of fruit sold out on the same day. The shops on Rapa sell very little local produce - occasional lettuces, cabbages or tomatoes, and once a month there are eggs from the only small-scale producer on the island; alcohol sales are banned on the island, while taro and the products of hunting, fishing and gathering are not sold for money. Fuel supplies are vital to run the two large communal power generators that provide electricity to the hundred or so households on Rapa, purchased via prepaid cards sold at the town hall. Some individual consignments of sacks of flour, a barrel of fuel ("Thirty thousand [francs cfp] for a barrel, it's expensive!" - equivalent to around $€ 250$ ) or crates of twelve litres of beer are received with feverish excitement when the cargo ship arrives.

\section{2- The three components of the Polynesian food supply}

The food resources available in French Polynesia today come from three different channels: monetary acquisition; state aid and transfers of public funds - as in subsidised products and food assistance for individuals and families; and finally subsistence consumption. Their relative proportions vary according to the household's socio-economic profile and its distance from the Tahiti urban area. Thus monetary income accounts for the major portion of the food supply for Tahitian families, while subsistence consumption covers the greater part of the food supply for households on the island of Rapa (Serra-Mallol, 2013).

2.1- High income inequality and policies driving excess consumption

Monetary incomes in French Polynesia are unequal and artificial: the result of overremuneration in the public sector combined with a minimum wage that is lower than the 
minimum in the French mainland and lower levels of social protection - this inequality becoming increasingly pronounced closer to the urbanised areas (Herrera and Merceron, 2010). This overseas territory remains the only French territory with no income tax for physical persons, and with no minimum welfare, income or unemployment benefits - a situation that exacerbates social and economic inequalities. Prices are high, estimated at between $40 \%$ and $80 \%$ above average French mainland prices for food, a differential that has been increasing since 2010 (ISPF, 2016). Food expenditure remained high in 2016, representing $24.7 \%$ of the total budget of a Polynesian household, as compared with $14.3 \%$ on average on the French mainland; food costs remain the primary driver of local price inflation. The Austral archipelago has the lowest average household income in the whole of French Polynesia: in 2000, average monthly monetary income per household, including social benefits and income from capital, barely reached $€ 1,400$ - as compared with $€ 3,100$ for the territory as a whole and $€ 3,800$ for the Tahiti conurbation alone. Given the substantial size of households in the Austral Islands, if we look at average income per consumption unit this differential becomes greater still. In Rapa, these figures are even lower: average household income was around $€ 1,220$ in 2010 during our research field, while $33 \%$ of households reported average monthly income lower than $€ 670$. On average, during the research period, $30 \%$ of working-age residents were in waged employment, $29 \%$ of these in the public sector (the local administration is the island's largest employer), 22\% were in subsidised employment, while $48 \%$ were self-employed, $44 \%$ of these being farmers, fishers, and/or craft workers. Nearly half of the working-age people in employment in Rapa, therefore, described themselves as self-employed in that year, as compared with $20 \%$ in Tahiti and just $10 \%$ in mainland France (Délégation aux Etats Généraux, 2009). One registered unemployed person in two is a high school pupil or a student, and the official unemployment rate (around 14\%) is lower than across the Austral archipelago as a whole (around 23\%), with an unemployment rate for men that is the lowest in the whole of French Polynesia.

In Tahiti, the least wealthy families set a budget for their supermarket shop and the women keep track of their purchases as they go so as to control their expenditure. The total shop can cost between $€ 150$ and $€ 250$, the shopping trolleys overflowing with crates containing several kilos of frozen meat or poultry, large bags of rice, frozen vegetables, and catering-sized packs of butter, oil, sugar and mayonnaise. This big monthly supermarket shop is supplemented by more or less daily purchases in the small neighbourhood stores, mainly fulfilling immediate consumption needs: specific items needed for that day's meal (a sauce, canned foods, instant coffee, a packet of rice) and snack foods (sweets, cakes and pastries, drinks). Expenditures are 
lower here than in the supermarket, always less than around $€ 40$, often below $€ 20$. Despite being less well stocked and often having higher prices, the small stores have the advantage not just of proximity but also of offering monthly credit facilities.

Looking beyond the practical aspect and the range of foods available, food buying is always regarded as an indicator of status in Tahiti: an act that demonstrates possession of monetary resources, a sign of belonging to "modern" society - as distinct from the "old times" when people had to work the land and be content with eating the produce of land and sea (SerraMallol, 2010). These days monetary dependency is regarded as more gratifying than dependence on working the land.

\section{2- A half century of a massive public funds transfers}

Directly or indirectly, Polynesian households benefit from the cumulative impact of public fund transfers delivered via a range of different schemes and channels: European Union funding schemes for peripheral regions, state funding via planning agreements and the postnuclear support programme, regional funding as the overseas territorial administration has its own funding capacity and its own administrative subdivisions, and finally local schemes either equalisation schemes of a classic nature or specific local arrangements (subsidised employment contracts, urgent medical and food assistance, social housing, etc.). In terms of healthcare provision, French Polynesia has a generous level of protection and cover following the 1995 introduction of Protection Sociale Généralisée (universal social protection): in 2007, 99\% of the population were covered by this system (Délégation aux Etats Généraux, 2009). As with social housing, the system is co-funded by the French state and the territorial authority, which has the administrative autonomy to offer the population a relatively large number of different kinds of support, even if these still remain inadequate: subsidised temporary work contracts, free provision of construction materials, subsidised inter-island transport, etc. These public funding flows represent a substantial addition to households' monetary incomes - but can also lead to political clientelism as the funding sometimes circulates within well-established redistribution channels.

With regard to food there are very few social programmes in place, the sole exceptions being the tax exemption, since 1983, for certain products deemed "basic necessities" - many of them foodstuffs (the list, drawn up by the local council of ministers, is subject to some dispute and varies accordingly), as well as assistance in the form of food vouchers for the most disadvantaged households. This import- and consumption-focused policy favours the inflow of external products to the detriment of developing local production, which nonetheless 
clearly remains important in informal channels (gifts and exchanges, roadside vending). Some local administrations subsidise the provision of school meals, as in the Papeete conurbation and in Rapa; these subsidies are often supplemented by donations from local voluntary and community initiatives.

As Rapa has no construction or civil engineering companies on the island, the administration uses subsidised territorial contracts for its various projects - mainly covering a one-month period, although they can last up to twelve months. The municipal council ensures that as many people as possible benefit from these contracts (of which twenty or so are granted each year) by rotating the families involved. Public funding in the form of subsidised contracts, the provision of low-cost social housing and subsidised construction therefore represent an ongoing resource contribution for the majority of the Rapa population.

Polynesian society therefore remains highly unequal and dependent on the outside world, mainland France in particular, due to food acquisition habits that are largely monetised and consumption habits favouring imports: only one quarter of Polynesian agricultural land is properly cultivated today and the food self-sufficiency level is barely $20 \%$. The massive development that has taken place during the past half century has helped to create an economy of over-consumption and an inflated public sector - absent, in its extreme forms, in Rapa.

\section{3- Subsistence consumption providing differentiated access to food resources}

\subsection{1- Subsistence consumption as a driver of the social bond}

Two very different approaches to food have been encountered, based on access to resources in each case. In Tahiti, food is experienced as a constraint, because it is monetised, with attention focused on price and quantity. In Rapa, by contrast, food is perceived as a source and guarantor of a form of autonomy - but also of the social bond, freedom and at the same time a strong attachment to a land whose resources are shared.

Tahiti's food world has expanded substantially over the last forty years or so with the organisation and modernisation of its retail distribution system, which has opened up even further to imported products - imported mainly from within the Windward Islands. Yet the convenience offered by these new products has led to the progressive neglect, and the decline in the daily diet - chiefly in favour of rice - of plant foods which require a large input of labour either to grow them (taro, tubers), or to prepare them ('uru and tubers). The same shift is observed in school canteens which socialise children around the dishes and produce they 
provide - which have been mainly European in type for the past 30 years or so (Serra-Mallol, 2010).

It is increasingly difficult to obtain supplies of local products in Tahiti, due to their lack of availability in supermarket outlets. Yet food provision, which can account for up to $50 \%$ of the available budget in the least wealthy households, is still supplemented by significant subsistence consumption - significant both in volume and in the variety of products it covers. This is true not just of producers themselves - a small group - but extends to include a much larger group of households via family ties: in today's Tahiti, subsistence consumption is based on gifts and exchanges rather than on subsistence production, and the decision to consume traditional local products depends on the possibility of accessing their sources of production, either directly or via the intermediate family network.

Adding together food expenditure and subsistence consumption, we estimate that around $30 \%$ of the average annual value of food consumed at home in the Society Islands is derived from subsistence consumption; this level is lower (22\%) in the urban part of Tahiti, compared with $40 \%$ for the rest of the Society Islands. This kind of calculation of course has its limitations but these levels of subsistence consumption are nonetheless much higher than in mainland France, where the proportion is currently estimated at around 5\%. Subsistence consumption therefore still represents an important source of food for around half of the Polynesian population - i.e. specifically for the indigenous $M a$ 'ohi.

This level of subsistence consumption increases as we move away from the Papeete conurbation - it stands at $85 \%$ in Rapa - but remains significant even within this urban area, testifying to its enduring importance in Tahitians' diet and to the persistence of an interhousehold exchange network which often extends beyond any specific neighbourhood, reaching out to other islands. When raw, unprocessed food products are sent from remote islands, for example, these are then distributed to siblings and friends. The receipt of this kind of gift, from the recipient's island of origin, is freighted with a strong emotional significance which is not in any way commensurate with its strictly economic value: these foods are reputed to have a taste and a flavour different from those of the same foods purchased in shops. Gifts made for shared use in the family home "in the islands" (far from Tahiti) sometimes seem to have a strategic aspect to them, too: a kind of manoeuvre designed to secure sympathy from the rest of the family based there, staking a claim in the complex web of family land ownership claims.

Claude Robineau (1985) highlighted the various forms of mutual assistance available within Tahitian village communities: arofa, tauturu and prestige. This author also found these 
characteristic relationship modes still in evidence in relation to food (Serra-Mallol, 2010). The first, arofa, is mutual assistance based on a feeling of love or compassion, via the provision of foods or a daily meal for close relations. Providing accommodation - equated in Tahiti with the fact of feeding someone ( $f a^{\prime} a^{\prime} a m u$ 'a), often a member of the wider family - is also part of this feeling of arofa: hospitality, "nourishment", is not refused even to distant family members, at least for a time. If the person taken in is regarded as adult-dependent, a minor, a student, or vulnerable, they are fed and housed and become part of the family. Tauturu is material assistance through the provision of goods and services - by making a plot of land available for cultivation, for example, or giving one's own time for an activity or project ('ohipa tauturu, work assistance); or by giving money, especially to the parish (moni tauturu, financial assistance). The relation of prestige was more evident in the past, as when the owner of a large fishing net traditionally asked the population to contribute to preparations for a joint fishing expedition; making fruit-growing land available to local canteens can be included in this category, as can the gift of land to a penniless young household.

Economic factors may underpin relationships in the Society archipelago today but this does not prevent the existence of relationships based on family ties, and thus involving attachment to a particular land, and on community, which can be seen in the level and intensity of nonmonetary food provision. Subsistence food consumption remains important today - even in the most urbanised areas of French Polynesia.

\subsection{2- Collective food resources in Rapa}

The key point of difference between Tahitian society and Rapan society is that the latter has decreed food resources - of both land and sea - to be collective property. In the 19th century the land was managed collectively: at the level of the family group by a chief, and at island level by the To'ohitu or "council of seven", a traditional council formed of representatives from each of the seven major ancestral groups on the island (Stokes, 1930). This council is believed to have been established following the land redistribution undertaken in 1887, the year when French Civil Code provisions on land tenure were applied to the rest of Polynesia. In 1912, Caillot (1932) noted that "all the natives are currently sole owners of all the lands on the island": today Rapa remains a settlement within French Polynesia where the administration has not implemented a system of land registration.

For the people of Rapa, land has no material value in itself: only its amenities and developments have material value, in particular those undertaken for the subsistence cultivation of taro. Even back in 1960s, Hanson (1970) reported that Rapa's co-owners were 
relatively unconcerned about land on its own count, considering that "the land belongs to everyone". In the end the Rapans institutionalised this situation with an administrative act that re-established the To'ohitu in 1984, making the land of Rapa collective property, owned by all the Rapa people. All those of Rapan descent are therefore guaranteed access to land on the island where they can build a house, grow taro and other vegetables and fish, in order to feed their family.

The To'ohitu is composed of ti'a'au, "custodians of the land", appointed for life by the members of the major family groups on the island (groups which are less clearly distinct today); today the holders of this title, who can be male or female, sit on a council whose membership is renewed every five years ${ }^{4}$. This council has established collective ownership of the land and its aim is to "ensure that no registry of land is undertaken, that no person can hold title to property, that no rental of land can be undertaken, that no reservation of land can be undertaken and that no sale transaction is accepted" (internal regulations, 2002 p. 2). Recognised by the French administration simply as a "citizens' association", the To 'ohitu has the power not of physical enforcement but of a moral injunction. Anyone who contravenes the established rules will therefore "be sanctioned by the council of elders. If they do not respect the sanction they will be judged by the population" (articles 24 and 25) and therefore exposed to public disgrace, ha'a'ama, a powerful feeling but not always sufficient to deter some behaviours contrary to the collective interest - such as night fishing in the prohibited area or the appropriation of a taro plantation recently neglected by its designated "manager".

The management of the sea area within Rapa's territorial waters is overseen by a dedicated rahui committee comprised of fishers elected annually by their peers. This committee supervises the observance of the general ban on net fishing, creel fishing, night fishing and the use of a toxic plant-based substance (hora), along with observance of the rahui (a ban sanctified by the pastor) imposed across the whole eastern side of the island for two nautical miles out to sea. All fishing in this area - by night or by day - is prohibited all year round except for two days when the rahui is publicly and ritually lifted by decision of the committee: one in October, solely for catching lobster (for use as bait in the traditional method of stone fishing, and as a special dish to honour distinguished visitors today), plus a second day for general fishing in mid-December when children attending school away from the island have returned home, in order to prepare family and community festive meals for the holiday season.

\footnotetext{
${ }^{4}$ Please see Serra Mallol (2013) on these regulatory issues.
} 
On ordinary days the main meal is the midday meal of taro (sometimes replaced by rice) and fish, after the work in the fields is done; as in the rest of Polynesia (Serra-Mallol, 2010), the evening meal is just a snack - hot coffee and bread or taro (which plays the role of bread in Rapan meals). Food's festive aspect comes to the fore in the family, religious and community events that punctuate daily life in the two villages, actively involving all community members in preparations for the meal. The preparations are organised in advance, with everyone undertaking one or more tasks according to the community's needs, and food production activities are always segregated by gender: the women make bread, prepare the popoi (a paste made from taro) and cook; the men fish and bring the beef and goat meat. The community meals - at which festive dress is worn - are preceded by speeches and prayers.

Rapa has undergone significant changes, modifying the structure and organisation of its ancient society. Yet nonetheless there is still a strong feeling of identity and unity - preserved both by the island's physical isolation and by the desire for a lifestyle that remains largely self-sufficient and community-based, in its daily routines and above all in its festivities.

\section{3- Renewed meaning, control over food}

Rapa represents for Tahiti what Tahiti represents for the West: a myth of paradise and abundance. In Rapa, subsistence consumption activities allow a degree of control over the food supply. The circular nature of subsistence consumption fosters the creation and maintenance of social bonds, while the active aspect of providing for one's own needs restores meaning to food and the whole of the food system.

\section{1- Control of land resources: myth or reality?}

Economic and social inequalities are on the rise in French Polynesia, and the fiscal and social system put in place is proving inadequate, indeed even detrimental to the least wealthy, the population living as ma'ohi. In contrast to the feeling of impotence and injustice now experienced by Tahitians, and the many disputes arising from joint ownership of land, the people of Rapa feel relative control over their access to natural resources and the satisfaction of being an exception in a globalised world they know today through television. If Tahiti symbolises an earthly paradise for Westerners, the same is all the more true of Rapa: in Tahiti, Rapa is seen as the archetype of the Polynesian island, living in community conditions which remain traditional, symbolising the food independence closest to the ideological ideal of the ma'ohi discourse.

This "paradise" discourse was picked up by some missionaries and perpetuated all through the 19th century (Fer \& Malogne-Fer, 2000), portraying the Rapans as custodians of a lost, 
remote land chosen by God, earthly cherubs of a doomed culture that must be defended at all costs. Defended from the outside world and its harmful influences, hence the To'ohitu's refusal to release land to build an airport on the island in 1996 - despite some support for the idea in a popular consultation, or the fears expressed about plans to set up an inter-island shuttle service to transport goods and travellers within the Austral archipelago. Defended from strangers, non-Rapans, because moving to the island depends on one vital, decisive precondition: having Rapan ancestry. Defended, too, from what is experienced as acculturation, the intrusion of an external lifestyle with the potential to supplant local customs and habits, hence the return of the Rapan language for public meetings and municipal information purposes rather than the reo ma'ohi language that missionaries used to spread the Bible message. Defended, finally, in its very substance, on land and sea, by the use of prohibitions, rahui, and the refusal to deploy products regarded as dangerous in their use of these resources: weedkillers, insecticides and chemical fertilisers for agriculture, non-sustainable techniques in fishing. Whenever the Rapa say "here is paradise" it is by comparison with Tahiti and the reference is always to the latter's disadvantage, just as the present is inferior to the mythicised past in local discourse. Rapans point to the low level of monetisation in the local economy, the mutual support, and the fact that unemployment cannot happen here.

While this way of seeing things may reflect the internalisation of an Edenic discourse, it is important not to underestimate the sheer hard work involved in subsistence production. Making a batch of bread takes five to six hours, from getting the wood and tending the fire until the embers are hot enough, while simultaneously preparing the dough, through to baking the bread, sometimes in very smoky conditions. Working in the taro plantations is physically demanding, with sticky mud up to calf level and a backbreaking stooping posture - like work in the rice fields. And fishing trips in the heavy swell can cause seasickness even among experienced sailors who must nevertheless go on with their task.

\section{2- Subsistence production and giving: circular activities}

The work of providing food is undertaken collectively, bringing together members of different families to undertake the same tasks described by Hanson (1970): planting mikaka taro, harvesting coffee and gathering wood, as well as fishing, hunting and food gathering. The fruits of this labour are then shared among the various members of the families who were involved or represented in the tasks.

Subsistence production provides the guarantee of a daily livelihood that is mainly achieved through monetary resources on the other islands. This gives the Rapans a feeling of 
collectively controlling their own lives and of pride in this - "we don't need money to live here" is a comment heard on a regular basis. This observable propensity to well-being among the Rapan people is largely derived from the way they analyse and interpret their daily experiences, especially the experience of subsistence production and exchange within the context of expanded domestic production.

This commitment to shared management and to collective and integrative, circular values over individualistic, differentiating values, can also be seen at communal level, in the political sphere. For the last 30 years, for example, it has been the custom for the mayor to organise twice-yearly public meetings, held on 14 July and 1 January on the square in front of the town hall - a kind of Polynesian agora which gathers together all Rapans present on the island on the day of the meeting. Non-Rapans are also invited to attend as observers. Everyone's opinion is respected, at least in its expression: everyone who talks is allowed to say their piece without interruption, even if their speech is a long one. Replies are made not directly to the person who just spoke but to the members of the administration and the To'ohitu opposite, or to the whole gathering, and humour is welcomed - indeed arguably indispensable. These meetings, held in the Rapan language, are an opportunity for the mayor to present and gain approval for his projects, and to gather the views of the population on issues that need to be decided by the municipal council. For the people, they represent an opportunity to keep abreast of the various projects and to show their involvement by participating in the uninterrupted debate on community business, while also settling any differences they may have in the public arena.

\section{3- A renewed meaning for food and food activities}

In the 1960s, Hanson wrote that, while the Rapans had an abundant food supply, "Most of their economic activities by far [were] devoted to the food quest" given the time it took to get to the taro plantations and to the fishing areas out at sea. Today the availability of motorised vehicles (cars, motor boats) - even though the island's various taro plantations are located where motorised access is difficult or even impossible - and above all the more or less general ownership of domestic freezers, mean that food provisioning tasks are less frequent than fifty years ago. Food, though, remains a subject of constant concern and discussion, and still possesses the same "symbolic content. Food is their measure of happiness and security, of friendship and hospitality" (Hanson, 1970).

This contentment derives, firstly, from being able to access food in abundance ("here, everyone can feed their family, they only have to bend down") and always being able to serve 
excessive amounts to their guests. Among the questions people ask each other when they meet on Rapa is "What have you eaten?" or "What are you going to eat?" It is the contentment, above all, of getting together and eating in groups (Serra-Mallol, 2010), opportunities to do so being frequent on Rapa - as reported by Hanson (1970), Rapans claim that "food tastes better when many people eat together." Then there is the contentment that comes from security: there is never any need to go without food, and all the freezers in Rapan households are filled with fish, beef and goat meat, so much so that the Rapans have taken to using the communal cold storage facility to store their surplus food, for giving or exchanging with family and friends beyond Rapa via cargo shipments (Serra-Mallol, 2013). And while the risks of food insecurity are not entirely unavoidable - a notable example being ciguatera fish poisoning, affecting some of the fish Rapans most like to eat on a daily basis, which has made dozens of people ill since 2009 - overall food security, in terms of both quantity and quality, is ensured, and comes with a strong social and cultural component, too. Friendship and hospitality, because the contentment of eating is not just about the food itself - the fish, the succulent meat, as much taro as they can eat - but also and above all about eating it in the company of family or friends. Rapa is the only island in French Polynesia where the author has heard the traditional greeting Haere mai e tama'a ("Welcome to eat") genuinely offered to a passer-by from a nearby house: the invitation to eat is a constant here, whenever you are in the presence of someone eating or about to eat, and the person greeted in this manner sometimes accepts the invitation, for the pleasure of sharing.

Food provision activities are not regarded as work by the Rapans themselves, but as necessary and engaging social activities, operating not within "time that is abstract, void of content and measured with increasing stringency" but within "time that is experienced, that of daily life, non-uniform, variable and concrete" (Thoemmes, 2008). These activities bring rules into play calling for specific expertise or technical skills that are constantly evolving through experience, empowering the individual with a feeling of potential control. They demand a certain amount of effort to achieve a goal that is fixed but attainable and facilitate concentration and involvement in the activity itself. The objectives pursued on a day-to-day basis do not depend on normative temporal models imposed from outside but are developed by each individual within the activity: time becomes what the activity produces in the act of production itself (Bourdieu, 1994). Achieving these objectives depends solely on the individual ("little by little"), on the weather conditions or on the will of the gods.

Working the land or fishing, or making popoi, for example, are engaging activities with a subjective time experience very different from the dominant Tahitian experience of time. 
They enable the people undertaking them to have a global vision of the activity, its preparation and its end product, even if the latter is time-delayed (as in harvesting taro), because the activity itself - clearing the ground, turning over the soil, creating the irrigation system, planting cuttings, weeding, etc. - is purposeful in its own right and therefore returns an immediate sense of accomplishment. They give meaning to existence, enabling the Rapans to feed themselves, feed their family and offer gifts to others, while being part of a community network of gifts and exchanges with its own specific social timescales; and they give a sense of continuity, connecting present-day Rapans with their predecessors who undertook the same kind of activity in the past. They provide a certain satisfaction to those who undertake them, immersed in the activity without any awareness of time passing, forgetting themselves and the fatigue of physical work in the collective rhythm of the activity, which is sometimes accompanied by singing or laughter. In this respect they are the opposite of activities such as office work or a position as a labourer in a Tahitian business: they are neither alienating nor a source of frustration and the process of accomplishing them is reassuring in its familiarity.

Unlike consumption that is a source of anxiety and inequality, the voluntary activity of subsistence food consumption restores meaning not just to food itself but also to the food system and the social context as a whole. It provides the community with food that they choose, share, produce and process together, following re-appropriated timescales and production methods, food that is freely exchanged within a community with a shared sense of purpose and direction, and which aims to preserve this capability for future generations.

\section{Conclusion}

A significant aspect of the crisis of the food system in contemporary France, over the past 40 or so years, relates to the desymbolisation of food, previously embedded within a sociotechno-cultural system that gave it meaning, by the monetised externalisation of its productive and culinary functions (Fischler 1990, Poulain 2002). The growing awareness of this profound loss, and of the urgent need to reconstruct this meaning, can lead to selective forms of empowerment involving the re-appropriation and collective management of local resources, and the resignification of social temporality. This example of a situation on the outer reaches of the French experience - dually so, both geographically and socio-politically (Wallerstein, 2004) - illustrates the construction of a distinctive food model that reconciles consumers with their physical, social and cultural environment. 
The drive to re-appropriate one's food systems can take various forms besides the collective management of resources in Rapa. In the absence of any strong demands to reclaim the country's common agricultural land, this drive is currently expressed in Tahiti and Mo'orea through the creation of shared community gardens, and by reclaiming the 'heritage' (Bessière, 2012) of local food resources (agricultural fairs, an 'uru festival, local food markets, etc.), as well as through growing concerns for the social and physical environment (organic food, local food) and ethical dietary choices (faith-based choices, veganism) - even if these are still largely the preserve of minority groups. It can also be seen in demands for collective land tenure in New Caledonia, in the continuing attachment to a traditional system based on selfsufficiency and community life in Wallis, and - looking beyond the societies of Oceania's islands - in local alternative models for reappropriating the food system.

If the disembedding of the economic is a social and political product, then its re-embedding in networks of interpersonal relationships based on a common culture and common values is a social and political product, too. Even asking ourselves the question about the meaning and purpose of economic activities, and especially about the ways we source our food and how these relate to society and culture, already implies envisaging the creation of more cohesive social networks, more flexible and open social temporalities, and collective forms of organisation operating across plural and complementary forms of activity (Wallerstein, 2004) rather than solely within the model of the monetary and commercial economy. This political and economic re-embedding in the social and cultural calls for the creation of regulatory arrangements and frameworks for collective negotiation between different social actors, as well as public and participatory modes of political regulation at all levels, as in the example of Rapa or shared community gardens.

Within the web of relationships connecting market, state and civil society, adding the relational dimension of gift and exchange and subsistence consumption into an individualised food system can help to balance out the effects of a monetary economy which may have liberated us in some ways but which currently alienates and commodifies, and of a failing institutional redistribution by the state and its territorial administrations which can stigmatise the recipients. This paves the way for establishing a plural economy in which socio-economic activities can have different meanings when operating within different institutional forms the essential pre-condition for achieving local social control over food choices, a collective reappropriation of the food issue, and a rediscovery of the meaning of food and food practices by eaters. 
Translated by Susan Mackervoy and Cynthia Schoch 
Bibliographic references

Baré J.F. (1987) Tahiti, les temps et les pouvoirs. Pour une anthropologie historique du Tahiti post-européen, Paris, ORSTOM, Travaux et Documents 207.

Bessière J. (ed.) (2012) Innovation et patrimoine alimentaire en espace rural, Paris, Quae.

Bourdieu P. (1998 [1994]) Practical Reason: On the Theory of Action, Cambridge, Polity Press.

Caillot E. A.C. (1932) Histoire de l'île Oparo ou Rapa, Paris, Librairie Ernest Leroux.

Délégation aux Etats Généraux (2009) Les Etats Généraux de l'outre-mer en Polynésie française, Papeete, Haut Commissariat de la République en Polynésie Française-Présidence de la Polynésie Française, 7 vol.

Ellis W. (1829) Polynesian Researches, during a residence of nearly six years in the South Sea Islands, London, Fischer, Son \& Jackson, 2 vol.

Fer Y. and Malogne-Fer G. (2000) Tuaroi. Réflexions bibliques à Rapa. Conversion au christianisme et conservation identitaire en Polynésie française, Papeete, Haere Po.

Fischler C. (1990) L'Homnivore: le goût, la cuisine et le corps, Paris, Odile Jacob.

Godbout J. T. (1998 [1992]) World of the Gift, Montreal/London, McGill-Queen's University Press.

Hanson F. A. (1970) Rapan Lifeways: Society and History on a Polynesian Island, Boston, Little, Brown and Co.

Herrera J. and Merceron S. (2010) Les approches de la pauvreté en Polynésie française: résultats et apports de l'enquête sur les conditions de vie en 2009, Paris, Agence Française de Développement, Document de Travail 103.

ISPF (2016) La Polynésie française 39\% plus chère que la métropole, Points Forts 01, Papeete, Institut de la Statistique de la Polynésie Française.

Jacquier H. (1949) Contributions à l'étude de l'alimentation et de l'hygiène alimentaire en Océanie Française, B.S.E.O. 86, VII(16), 584-606.

Levy R. I. (1973) Tahitians. Mind and Experience in the Society Islands, Chicago, University of Chicago Press.

M. (1954 [1950]) The Gift, London, Cohen \& West.

Moerenhout J.A. (1959) Voyages aux îles du Grand Océan, Paris, Adrien Maisonneuve, 2 vol. Oliver D. (1974) Ancient Tahitian Society, Honolulu, University Press of Hawaii, 3 vol.

Polanyi K. (1957) The Great Transformation. The political and economic origins of our time, Boston, Beacon Press.

Pollock N. (1992) These roots remain: food habits in islands of the central and eastern Pacific since western contact, Laie-Hawaii, Institute for the Polynesian Studies.

Poulain J.P. (2017 [2002]) The sociology of food: eating and the place of food in society, London, Bloomsbury Academic.

Robineau C. (1985) Tradition et modernité aux Iles de la Société, Paris, ORSTOM 100, 2 vol. Serra-Mallol C. (2010) Nourritures, abondance et identité: une socio-anthropologie de l'alimentation à Tahiti, Papeete, Au Vent des Iles, coll. Culture Océanienne.

Serra-Mallol C. (2013) Entre local et global: l'alimentation en Polynésie. Le cas de Tahiti et Rapa, Anthropologie et Sociétés 37(2), 137-153.

Stokes J.F.G. (1930) Material Culture of Rapa, Honolulu, Bishop Museum, typescript, 5 vol. Thoemmes J. (2009) Sociologie du travail et critique du temps industriel, Temporalités 8, available at: http://temporalites.revues.org/92.

Wallerstein I. (2004) World-Systems Analysis: An Introduction. Durham, N.C; London, Duke University Press. 